\title{
Entrepreneurial Potential of Small scale Beekeeping in Rural India: A Case in Kanniyakumari district, Tamil Nadu
}

\author{
M. Esakkimuthu* and VLV. Kameswari ${ }^{1}$
}

\begin{abstract}
Department of Agricultural Extension and Communication, College of Agriculture, Govind Ballabh Pant University of Agriculture and Technology, Pantnagar-263 145, U.S.NagarDistt, Uttarakhand, India.
\end{abstract}

\begin{abstract}
About half of India's population is supported by agriculture. Development of any nation depends primarily on the role played by entrepreneurs and entrepreneurship development among rural people is increasingly being recognized as a means of overall development of rural community. Small and medium scale agri-enterprises play an important role in creating employment opportunities in rural area. Beekeeping is one such remunerative agri-enterprise. At global level honey production from India is very small; among the states Tamil Nadu stands rank second in honey production. Hence, the present study was undertaken with the following objectives; to assess the entrepreneurial potential of beekeepers in Kanniyakumari district. It has nine blocks and village having maximum number of beekeepers was selected from each block. In the next stage of sampling, 50 per cent beekeepers from each village were selected using simple random sampling. Thus, a sample of 213 respondents was selected for data collection using a pretested interview schedule. On the basis of the findings it is concluded that majority of the beekeepers had high level of economic motivation, need for achievement and risk taking ability. On the other hand, it was found that majority of the respondents had only medium level of innovativeness and self-confidence. Overall entrepreneurial potential of majority of the beekeepers was high.
\end{abstract}

Keywords: Agri-enterprise, beekeeping, entrepreneurial potential, innovativeness and rural community

\section{INTRODUCTION}

India is an agrarian country. Over $58 \%$ of India's population is supported by agriculture. Even while India's industrial and service sectors are growing by leaps and bounds, growth rate of agriculture is below $2 \%$. However, in the long run, growth of other sectors is invariably linked to the fortunes of agriculture due to intricate forward and backward linkages. Hence, India's economic status continues to be determined by agriculture sector, and the situation is not likely to change in the foreseeable future.

\footnotetext{
1 Department of Agricultural Extension and Communication, College of Agriculture, Govind Ballabh Pant University of Agriculture and Technology, Pantnagar-263 145, U.S.Nagar-Distt, Uttarakhand, India.

* Corresponding Author: esakkimuthu418@yahoo.com
} 


\section{Small scale agriculture in India:}

Small and marginal holders face several problems in agriculture like small and fragmented land holdings, shortage of good quality seeds, problem of irrigation, lack of mechanization, inadequate storage facilities, scarcity of capital, absence of marketing network, lack of value addition technology, non-availability of quality inputs, lack of timely credit, etc These factors make agriculture economically unviable for small holders. While their farm sizes may be small, marginal and small farmers contribute significantly towards both diversification and food security. It has also been pointed out that small holdings are equal or better than large holdings, but that it is not enough to compensate for the disadvantages faced by small holders. Hence, the economic viability of marginal and small farmers is crucial for livelihood in rural areas and the entire country. However, small scale agriculture can be made profitable through product diversification and entrepreneurship. There is an urgent need to nurture small holders and turn them into agripreneurs, who are not just farmers, but are also thinkers, risk takers and innovators. Agro-based industries provide an excellent opportunity to farmers for local entrepreneurship and employment generation thus improving their socio-economic conditions. Small scale enterprises play an important role in employment creation, resource utilization, income generation and in promoting change in a gradual and peaceful manner. In rural India, there is tremendous scope for agri-enterprises such as mushroom cultivation, lac culture, horticultural seedling production, sericulture, ornamental plants production and paddy cum pisiculture, etc. which can not only increase the farmers income but also help in diversification. Beekeeping is such remunerative agri-enterprise.

\section{Economic development through entrepreneurship:}

In India, after independence, the government decided to pursue the path of state sponsored and planned economic development. As a part of this strategy, individuals or group enterprise and initiatives were encouraged, assisted, guided and regulated by the state in various ways, so that their activities can have visible impact in the form of economic transformation along the lines considered appropriate and desirable by the state. The idea behind this was that persons who have no financial resources or managerial background could be induced to start small enterprises, which would be effective tools for widening the entrepreneurial base in the country. Micro, small and medium enterprises play important role in employment creation, resource utilization, and income generation and in promoting change in a gradual and peaceful manner. In this endeavour, behaviour of the individual has been highlighted as a major contributing factor and, therefore, supply of entrepreneurs is being recognized as critical to development process.

\section{Beekeeping in India:}

Small and marginal holdings constitute $80 \%$ of the total land holdings in India. They face several challenges which include lack of access to credit, technology, irrigation facilities, inputs and market. While their farm sizes may be small, marginal and small farmers contribute significantly towards both diversification and food security. It has also been pointed out that small holdings are equal or better than large holdings, but that it is not enough to compensate for the disadvantages faced by small holders. Hence, the economic viability of marginal and small farmers is crucial for livelihoods in rural areas and for the entire country. To improve agricultural productivity or income of the farmers, it is necessary to develop an entrepreneurial culture and organizational competencies among farmers. There is an urgent need to nurture local agripreneurs, who are not just farmers, but are also thinkers, risk takers and innovators. Agro-based industries provide an excellent opportunity 
to the farmers for local entrepreneurship and employment generation, thus improving their socio-economic conditions. In the rural India there is tremendous scope for agrienterprises such as mushroom cultivation, lack culture, horticultural seedling production, sericulture, ornamental plants production and paddy cum pisiculture, etc. which can not only increase the farmers income but also help in diversification.

Apiculture is an age old tradition in India but has the potential to develop as a prime agrihorticultural and forest based industry. Honey production is a lucrative business and it generates employment opportunities for farmers, farm women and rural youth. Apiculture is an economically profitable enterprise and can be a useful enterprise as it can add to the income and improve the economic condition of the farmers. There is enough scope for taking up beekeeping on a commercial scale. Beekeeping has a special advantage in India where majority of the farmers are small or marginal land holders and a large area is under horticultural crops.

\section{Beekeeping in Tamil Nadu:}

Beekeeping has a long tradition in Tamil Nadu, which is the second largest producer of honey in India. Both natural and cultivated vegetation in Tamil Nadu provide immense scope and potential for development of beekeeping ventures. Beekeeping ventures in Tamil Nadu predate establishment of Khadi and Village Industries Commission (KVIC) and serious efforts in this field were taken up since 1924. In 1924, Dr. Spencer Hatch, the Secretary of the Marthandam Young Man Christian Association (YMCA) trained farmers in scientific beekeeping and also popularized Newton's hive box (a movable frame hive box) and honey extraction machine. Marthandam Beekeeping Society (MBS) was formed in 1937 for the collection and marketing of honey in the state. From 1957 onwards, KVIC has taken lead in collection and marketing aspects to promote the venture in the state. Tamil Nadu has greater scope for apiculture compared to other states in India due to large scale cultivation of horticultural crops. Beekeeping in Tamil Nadu is mainly aimed at producing honey and wax. But, it can be made more profitable by producing related products such as royal jelly, bee toxin, pollen and propolis, which have a very high demand in international markets.

\section{Entrepreneurial potential:}

Literature on entrepreneurship development views an entrepreneur as a person who fulfils a role or a function in the economy. An impressive array of literature is available on their functions, qualities, and behaviour. Most of the theories on entrepreneurship highlight the contexts that give raise to entrepreneurship and highlight the role of economic, social and cultural factors in the process. In contrast, there are several psychological theories that link inherent characteristics of an individual and the likely manifestation of entrepreneurial ventures. Some models suggest that entrepreneurship is essentially an outcome of interaction between various components of which an entrepreneur is the prime mover or starting point.

According to Krueger and Brazeal (1994), the actual occurrence of an entrepreneurial activity requires a pre-existing preparedness to accept that opportunity. This "pre-existing preparedness" is the entrepreneurial potential. But that in itself is not sufficient to trigger an entrepreneurial venture. It has to be followed by something that precipitates the decision to start and continue an entrepreneurial venture (Shapero, 1982; Reynolds, 1992). Individuals with entrepreneurial potential often do not have any serious intention towards starting a business till the right conditions appear or occurrence of a trigger event. Till such time, their potential lies dormant. Hence, entrepreneurial potential can be viewed not only as a pre 
condition and contributory factor for an entrepreneurial event but exists temporally prior to it.

According to Delmar's (1996) model on entrepreneurship has four concepts; viz: business performance, entrepreneurial behaviour, the individual, and the environment. According to him, business performance (success) is determined by environment; i.e. market. It is also determined by the entrepreneurial behaviour (actions taken by the entrepreneur), which in turn is also affected by the environment. Besides these, an individual's i.e; entrepreneur's abilities and motivation also affect entrepreneurial behaviour. This inherent ability may be defined as the entrepreneurial potential of an individual, which when combined with knowledge and requirements for a given task can give rise to successful entrepreneurial venture. Despite existence of a high entrepreneurial potential, a person may not become an entrepreneur as entrepreneurial activity does not occur in a vacuum. Instead, it is deeply embedded in a cultural and social context, human networks, and both social and economic conditions. In other words, high entrepreneurial potential does guarantee occurrence of entrepreneurial activity or its success. It merely increases the chances of both. There is a noteworthy distinction between those who would like to be entrepreneurs and those who actually become an entrepreneur. Entrepreneurial potential refers to an inclination, an openness, and a readiness to grasp a business opportunity; not necessarily a deliberate intention to become an entrepreneur.

A look at the research trends reveals that, studies on entrepreneurship are mainly focused on assessing the entrepreneurial skills and entrepreneurial behaviour. As such, very few studies are available on entrepreneurial potential and there is a huge gap in our understanding of how innate potential of a person interacts with conducive environmental factors to give rise to successful entrepreneurs. Even though some studies have been conducted in Tamil Nadu on adoption of beekeeping technologies, there are no studies on the extent to which beekeepers turn into entrepreneurs and on their entrepreneurial potential.

\section{Objectives of the study:}

1. To study the socio-economic and communication characteristics of beekeepers.

2. To assess the entrepreneurial potential of beekeepers.

3. To assess the relationship between socio-economic and communication characteristics and their entrepreneurial potential.

\section{METHODOLOGY}

\section{Locale of the study:}

The study was conducted in Kanniyakumari district of Tamil Nadu state. This district was purposively selected for the study due to several reasons. Firstly, a large number of people in this district have taken up small scale agri-enterprises including beekeeping (Mahendran, 2004). Secondly, more than $70 \%$ of honey produced in Tamil $\mathrm{Nadu}$ comes from Kanniyakumari district alone (Chandy, 2009). Thirdly, the Marthandam Beekeeping Society, which is one of the oldest organizations involved in promoting beekeeping in the country, is also actively involved in the promotion of beekeeping venture in the district. It also has a State Agricultural University (Tamil $\mathrm{Nadu}$ Agricultural University) which is actively promoting beekeeping through Agriculture College and Research Institute, Killikulam. The University organizes 
training programs and other extension activities on a regular basis technical support to beekeepers in the district. Fourthly, Kanniyakumari district is unique as it receives both south-west and north-east monsoon because of which honey production can take place throughout the year. Lastly, this district produces a wide variety of horticultural crops, which is essential for beekeeping.

\section{Selection of blocks:}

Kanniyakumari district has nine blocks. After consultation with experts from the Marthandam Beekeeping Society and faculty members at Tamil Nadu Agricultural University all the nine blocks in Kanniyakumari district were taken for the study.

\section{Selection of villages:}

One village from each block, having maximum number of beekeepers, was purposively selected in the next stage of sampling.

\section{Table 1. Sampling Plan}

\begin{tabular}{|c|c|c|c|c|c|}
\hline S. No & $\begin{array}{l}\text { Name of the } \\
\text { district }\end{array}$ & Name of the Block & $\begin{array}{l}\text { Name of the } \\
\text { village }\end{array}$ & $\begin{array}{c}\text { Total } \\
\text { number of } \\
\text { beekeepers }\end{array}$ & $\begin{array}{c}\text { Number of } \\
\text { beekeepers } \\
\text { selected }\end{array}$ \\
\hline 1. & \multirow{9}{*}{ Kanniyakumari } & Agastheeswaram & Kulasekharapuram & 56 & 28 \\
\hline 2. & & Thuckalay & Maruthakurichy & 34 & 17 \\
\hline 3. & & Rajakkamangalam & $\begin{array}{l}\text { Kesavarthanapura } \\
\mathrm{m}\end{array}$ & 64 & 32 \\
\hline 4. & & Thovalai & Thovalai & 48 & 24 \\
\hline 5. & & Kurunthancode & Thenkarai & 38 & 19 \\
\hline 6. & & Thiruvattar & Pechiparai & 66 & 33 \\
\hline 7. & & Killiyoor & Mathicode & 54 & 27 \\
\hline 8. & & Munchirai & Panikulam & 38 & 19 \\
\hline 9. & & Melpuram & Vilavancode & 28 & 14 \\
\hline $\begin{array}{l}\text { Total } \\
\text { number }\end{array}$ & 1 & 09 & 09 & 426 & 213 \\
\hline
\end{tabular}

\section{Selection of respondents:}

List of total number of beekeepers in each village was taken from the Marthandam Beekeeping Society which is actively involved in promoting beekeeping in the district. Out of this, 50 per cent beekeepers were selected for study using simple random sampling.

\section{Research design:}

A research design is the arrangement of condition for collection and analysis of data in a manner that aims to combine relevance to research purpose with economy in procedure. Analytical research design was used to meet out the objectives set forth for the study. 


\section{Measurement of entrepreneurial potential:}

For the purpose of study, an entrepreneurial potential scale (measuring instrument) was developed. This instrument was developed exclusively for beekeepers, to know their potentials. Finally, the scale consisted of 30 statements and it indicates that it is reliable, consistent and adopted to other Indian states also (Esakkimuthu and Kameswari, 2015). Entrepreneurial potential is defined as extent to which an individual is capable of becoming an entrepreneur. It was conceptualised as a combination of five components; viz: innovativeness, economic motivation, need for achievement, risk taking ability and selfconfidence. The sum of all five component score is an overall entrepreneurial potential of beekeepers.

\section{Data collection tools and techniques:}

A detailed structured interview schedule was used as a tool for data collection. Interview schedule consisting of open ended questions was developed for collecting data from the respondents. The interview schedule was prepared in English and was translated into Tamil before administering it to the respondents. The pilot test was conducted by the researcher to gain first hand information about various aspects to be studied, study area and to check the tool. Interview schedule was modified for final administration after pilot study.

\section{Statistical tools:}

Statistical analysis of quantitative data is an important aspect of research work, as it facilitates interpretation of the data. Data were analyzed in the light of objectives of the study and following statistical techniques were used.

\section{Percentage analysis:}

Percentage values were calculated to make simple comparison. These were calculated by dividing the frequency of particular cell by total number of beekeepers and multiplying by 100.

$$
P=(f / n) \times 100
$$

Where, $\mathrm{f}=$ Frequency of particular cell; $\mathrm{n}=$ Total number of beekeepers; $\mathrm{P}=$ Percentage

\section{Coefficient of correlation:}

Coefficient of correlation is a number computed from a set of data and summarizes the extent to which variations in one variable go together with variation in other variable. It was used to find out the relationship between two variables. Karl Pearson's formula of coefficient of correlation given below was used to find the relationship between two variables.

Where,

$$
\text { Co v. }\left(\mathrm{X}_{1} \mathrm{X}_{2}\right)
$$

$$
\operatorname{Var}\left(X_{1}\right) \operatorname{Var}\left(X_{2}\right)
$$

$r=$ Coefficient of correlation

$\mathrm{X}_{1}$ and $\mathrm{X}_{2}$ are the two variables

$\operatorname{Var}\left(\mathrm{X}_{1)}=1 / \mathrm{n} \sum\left(X_{1}-X_{1}\right)^{2}\right.$

$\operatorname{Var}\left(X_{2)}=1 / \mathrm{n} \sum\left(X_{2}-X_{2}\right)^{2}\right.$ 


$$
\operatorname{Cov}\left(X_{1} X_{2}\right)=1 / n \sum\left(X_{1}-x_{1}\right)\left(X_{2}-x_{2}\right)
$$

\section{RESULTS AND DISCUSSION}

\section{Socio-economic and communication characteristics:}

From the Table i revealed that majority of the respondents were educated up to primary level, had land holding of less than one hectare, belonged to medium size family, and earn up to Rs. 50,000 per annum. Majority of the respondents also have medium level of mass media exposure, extension agency contact, extension participation, credit orientation and have attended more than three training program. The above findings due to in Tamil Nadu, participation of old people in agriculture and allied sectors like beekeeping is quite low, which explain why most of the farmers belong to young and middle age group; educational status is a reflection of the highest literacy rate in Kanniyakumari district among all the districts of Tamil Nadu; majority of beekeepers are marginal farmers which is the general trend in Kanniyakumari district, due to the fact that most of the cultivable land has been sold to multi-national companies for industrial use by farmers who were attracted to handsome amount of money paid by corporate sector. Also, establishment of Kudambakkam atomic power station in Kanniyakumari district led to forced sale of agricultural land to the government at fixed rate by the farmers; medium size families have preference for beekeeping due to availability of household labour. The maximum family size in the study area was eight and the minimum size was one. On an average, each family in the study area had four members; annual income reflect the poor economic status of the farmers; medium to high level of mass media exposure among majority of beekeepers is due to high ownership and access to mass media like television, commercial FM radio, mobile phones; majority of the respondents were seeking technical guidance from the Marthandam Beekeeping Society. Marthandam Beekeeping Society is a pioneer beekeeping institution in Tamil Nadu and has most of the technical know-how, resources and it provides training and equipment to the beekeepers and most of the beekeepers participate in various extension activities like field day, field visit, demonstration, agri-science fair etc.

Table 2. Distribution of respondents based on socio-economic and communication characteristics

\begin{tabular}{ll}
\hline Characteristics & F \\
\hline Age & \\
Young & $92(43.19)$ \\
Middle & $92(43.19)$ \\
Old & $29(13.62)$ \\
Educational status & \\
Illiterate & $17(7.98)$ \\
Can read and write & $62(29.11)$ \\
Primary school level & $62(29.11)$ \\
Middle school level & $38(17.85)$ \\
High school level & $27(12.67)$ \\
College & $7(3.28)$
\end{tabular}




\begin{tabular}{|c|c|}
\hline Professional colleges status & 0 \\
\hline \multicolumn{2}{|l|}{ Land holding size (ha) } \\
\hline Marginal (Upto 1.00) & $197(92.49)$ \\
\hline Small (1.01 to 2.00$)$ & $15(7.05)$ \\
\hline Semi-medium (2.01 to 4.00$)$ & $1(0.46)$ \\
\hline Medium $\quad(4.01$ to 10.00$)$ & 0 \\
\hline Big (10.01 and above) & 0 \\
\hline \multicolumn{2}{|l|}{ Family size } \\
\hline Small (Below 5) & $149(69.96)$ \\
\hline Large (5 and above) & $64(30.04)$ \\
\hline \multicolumn{2}{|l|}{ Annual income (Rs) } \\
\hline Low (Upto Rs.50,000) & $183(85.92)$ \\
\hline Medium (Rs.50,001 - Rs.1,00,000) & $28(13.15)$ \\
\hline High (Rs.1,00,001 and above) & $2(0.93)$ \\
\hline \multicolumn{2}{|l|}{ Extension agency contact } \\
\hline Low & $53(24.88)$ \\
\hline Medium & $145(68.07)$ \\
\hline High & $15(7.05)$ \\
\hline \multicolumn{2}{|l|}{ Mass media exposure } \\
\hline Low & $36(16.90)$ \\
\hline Medium & $127(59.62)$ \\
\hline High & $50(23.48)$ \\
\hline \multicolumn{2}{|l|}{ Credit orientation } \\
\hline Low & $10(4.69)$ \\
\hline Medium & $172(80.75)$ \\
\hline High & $31(14.56)$ \\
\hline \multicolumn{2}{|l|}{ Training attended } \\
\hline No training & 0 \\
\hline One training & $11(5.17)$ \\
\hline Two trainings & $53(24.88)$ \\
\hline Three or more trainings & $149(69.95)$ \\
\hline \multicolumn{2}{|l|}{ Extension participation } \\
\hline Low & $26(12.20)$ \\
\hline Medium & $171(80.28)$ \\
\hline High & $16(7.52)$ \\
\hline
\end{tabular}

*Parenthesis indicates per cent

\section{Overall entrepreneurial potential:}

It was defined as the extent to which an individual is capable of becoming an entrepreneur. The capability was studied in terms of five sub-dimensions. The results presented in Table 3 reveal that majority 84 per cent of the beekeepers had high level of overall entrepreneurial potential. Further analysis was carried out to find out the distribution of the respondents across the five components of entrepreneurial potential. It was found that majority of the respondents fall under high level of economic motivation 83 per cent, need for achievement 
63 per cent and risk taking ability 98 per cent. Further, majority of the respondents fall into medium level of innovativeness 57 per cent and self-confidence 88 per cent. It is important to note that none of the beekeepers have low scores on any of the five components of entrepreneurial potential. As entrepreneurial potential was measured as a sum of all the five components and scores on these components range from medium to high for all beekeepers, it was found that majority have high overall entrepreneurial potential. The result is in conformity with that obtained by (Solanki et al., 2003; Subramanyeswari and Veeraraghavareddy, 2003; Suresh, 2004; Anitha, 2004).

\section{Sub-components of entrepreneurial potential:}

Risk taking ability: It is defined as the degree to which a beekeeper is oriented towards taking risk and facing uncertainty while running the beekeeping enterprise. A glance at Table 3 shows that majority of the beekeepers had high level of risk taking ability. This result is due to an extremely high risk taking ability among the beekeepers may be explained in terms of their economic status where majority belong to low income group. As explained by (Cancian, 1967) in the context of adoption of innovations, people who are poor have very little to lose when they try out something new. Since the beekeepers are not very well off at present, they believe that taking risk can only better their condition whereas failure of the same will not lead to any significant deterioration in the condition. This result is similar to the findings of (Sarvanakumar, 1996; Sawant, 1999; Subramanyam, 2002; Jhamtani et al., 2003; Suresh, 2004).

Economic motivation: It is defined as the occupational success in terms of profit maximization and the relative value placed by a farmer on economic ends. A look at the result presented in Table 3 shows that majority of the beekeepers had high level of economic motivation. This findings may be economic motivation is important in prompting a person to perform more effectively so as to improve his or her economic status. A look at the annual income of the respondents indicates that a vast majority belong to the low income group (annual income upto Rs.50,000) and they want to better their living conditions. This explains high economic motivation among majority of the respondents. The results are in accordance with the findings of (Narmatha et al., 2002; Majunatha, 2002; Gour, 2002; Bhagyalaxmi et al., 2003; Chauhan and Patel, 2003; Patel, 2005).

Need for achievement: It is defined as the beekeeper's desire for excellence and to attain a sense of personal accomplishment. Data regarding need for achievement of respondents has been presented in Table 3 and reveals that 63 per cent of the beekeepers had high level of need for achievement. The above findings may be need for achievement is one of the prime factors that propels an individual to excel in any activity. A significant number of respondents (43 per cent) were youth (i.e. below 35 years) and an equal number belonged to middle age group. It is generally seen that young people have higher aspirations, a more positive attitude towards the future and greater confidence in one's ability to do well. This explains high to medium level of achievement motivation among the respondents. This also bodes well for any effort made towards promoting agri-preneurship in the area as entrepreneurs are supposed to have the highest need for achievement (McCelland, 1965). The result are in line with (Shailaja, 1990; Monica and Talukdar, 1997; Chandrapaul, 1998; Vijaykumar, 2001; Jhamtani et al., 2003; Suresh, 2004).

Innovativeness: It is defined as the degree to which a beekeeper is likely to adopt new idea, practice or technology related to beekeeping earlier than other beekeepers in the same social system. From Table 3 it can be seen that majority of the beekeepers had medium level of innovativeness. It may be the fact, according to (Rogers, 2003) people with more formal education, mass media exposure, change agency contact and information seeking regarding 
innovation (in this case reflected by extension participation) and those who have attended more number of training are likely to be more innovative. A look at the characteristics of the beekeepers reveals that they have high to medium scores on these variables which explains medium level of innovativeness of majority of the beekeepers. The result is similar finding with the result obtained by (Nomeshkumar and Narayanaswamy, 2000; Vijaykumar, 2001; Bhagyalaxmi et al., 2003; Suresh, 2004).

Self-confidence: It is defined as the degree of belief in one's own abilities in achieving the things one wishes. From the results presented in Table 3, it is seen that majority of the beekeepers had medium level of self-confidence and the obtained result could be during the study it was found that 69 per cent of the beekeepers have attended three training programs and an additional 24 per cent have attended two training programs. Training program not only impart skills and knowledge but increase one's own ability to interact and network with others. Training programs also increase the participants exposure to new ideas, techniques and people involved in similar activities. All these factors increase a person's self-confidence and his/her ability to take steps to implement his/her ideas which explains medium level of self-confidence among majority of the beekeepers. The result is support by studies by (Venkatakumaran et al., 2002; Naidu, 2004; Ranuji, 2006; Gangaiah et al., 2006).

Table 3. Distribution of the respondents based on their entrepreneurial potential

\begin{tabular}{ll}
\hline Category & F \\
\hline Overall entrepreneurial potential & 0 \\
Low & $33(15.49)$ \\
Medium & $180(84.51)$ \\
High & \\
Sub-components of entrepreneurial potential & \\
Risk taking ability & 0 \\
Low & $4(1.88)$ \\
Medium & $209(98.12)$ \\
High & \\
Economic motivation & 0 \\
Low & $35(16.43)$ \\
Medium & $178(83.57)$ \\
High & \\
Need for achievement & 0 \\
Low & $78(36.62)$ \\
Medium & $135(63.38)$ \\
High & \\
Innovativeness & 0 \\
Low & $123(57.75)$ \\
Medium & $90(42.25)$ \\
High & \\
Self-confidence & $24(11.27)$ \\
Low & $188(88.26)$ \\
Medium & $1(0.50)$ \\
High &
\end{tabular}

Correlation analysis: 
The relationship between socio-economic and communication characteristics of beekeepers and their entrepreneurial potential results presented in Table 4 reveal that, out of the ten independent variables viz; age, educational status, size of the land holding, family size, annual income, mass media exposure, extension agency contact, extension participation, trainings attended and credit orientation. Only two variables viz., educational status and size of the land holding were found to be significantly related to entrepreneurial potential of beekeepers. The findings may be the fact maximum number of beekeepers had high educational status. People with high education aspire for white-collar jobs in government and private sectors in urban areas and are reluctant to undertake agriculture and related small agri-enterprises as a means of livelihood; Farmers with small size land holdings are more willing to diversify and start small scale agri-enterprises like beekeeping to augment their income. On the other hand, when the size of the land holding increases, farmers usually prefer cultivating commercial crops or traditional food crops. Small farmers in the study area find beekeeping especially attractive due to low input costs, frequent training and ready market; difference in opinion among family members about diversification of agriculture and the kind of additional income generating ventures that could be taken up by the family.

Table 4. Relationship between socio-economic and communication characteristics of beekeepers and their entrepreneurial potential

\begin{tabular}{lll}
\hline Characteristics & Coefficient of correlation (r-value) & $\mathbf{t}_{\text {cal }}$ \\
\hline Age & $0.0068 \mathrm{NS}$ & 0.0988 \\
Educational status & $-0.1786^{* *}$ & -2.5624 \\
Size of the land holding & $-0.1489^{* *}$ & -2.1407 \\
Family size & $-0.1024 \mathrm{NS}$ & -1.476 \\
Annual income & $-0.1245 \mathrm{NS}$ & -1.7929 \\
Mass media exposure & $-0.1157 \mathrm{NS}$ & -1.6672 \\
Extension agency contact & $0.0502 \mathrm{NS}$ & 0.7266 \\
Extension participation & $-0.0691 \mathrm{NS}$ & -0.9989 \\
Trainings attended & $-0.1069 \mathrm{NS}$ & -1.5413 \\
Credit orientation & $-0.0046 \mathrm{NS}$ & -0.0667 \\
$* *$ Significant at 0.05 level & & \\
$\left(\mathrm{t}_{\text {tab }}=1.9712\right)$ & &
\end{tabular}

\section{CONCLUSIONS}

The present study concludes that in a developing country like India which is largely dependent on agriculture, beekeeping can be an important agro-based enterprise. The study reveals that, all the beekeepers had high level of overall entrepreneurial potential. The findings would help to improve the potential of entrepreneurs by analyzing their strength and weakness and improve upon their weakness, development of appropriate training programs for beekeepers by the beekeeping agencies, provide an in-depth understanding about entrepreneurial potential of beekeepers and can be utilized to design developmental strategies in beekeeping venture, extension policy makers to formulate appropriate beekeeping schemes for marginal and small holders, stream line strategies to overcome the problems experienced by the beekeepers in the beekeeping venture by beekeeping institutions. It also helps the government and their agencies to take various new initiatives in the field of agriculture and allied enterprise. While the current product of honey is low it can be improved by encouraging farmers to take up beekeeping on a large scale and providing necessary inputs and support the beekeeping venture. 


\section{ACKNOWLEDGEMENT}

This research financially supported by the university grant commission, India.

\section{REFERENCES}

Anitha, B. (2004). A study on entrepreneurial behaviour and market participation of farmwomen in Bangalore rural district of Karnataka. Thesis, M. Sc. University of Agricultural Sciences, Bangalore. 182p.

Bhagyalaxmi, K., Gopalakrishna Rao, V. and Sudarshanreddy, M. (2003). Profile of the rural women micro-entrepreneurs. Journal of Research. Acharya N. G. Ranga Agricultural University, Hyderabad, 31(4), 51 - 54.

Cancian, F. (1967). The effects of economic status and recent experience on innovative behavior under environmental variability-An experimental approach. Journal of Research Policy. 41(5), 833 - 847.

Chandrapaul, K. (1998). A study on entrepreneurial behaviour of vegetable growers in Krishna district of Andhra Pradesh. Thesis, M. Sc. Acharya N. G. Ranga Agricultural University, Hyderabad. 68p.

Chauhan, N.B., and Patel, R.C. (2003). Entrepreneurial uniqueness of poultry entrepreneurs. Rural India. 66(12), 236 - 239.

Chandy. M. (2009). Self-employment for rural women. Yojana. 33(9): 24-28.

Delmar, F. (1996). Entrepreneurship- theory and practice. Lund University Press, Eurpoe. 27(3), 247 - 270.

Esakkimuthu, M and Kameswari, VLV. (2015).International Journal of Farm Sciences. 5(1), $188-193$.

Gangadharan, K.K. (1993).Adoption of improved agricultural practices by pepper growers of Idukki district. Thesis, M.Sc. Kerala Agricultural University, Thrissur. 150p.

Gangaiah, G., Nagaraja, B. and Vasudevulu Naidu, C. (2006). Impact of self help groups on income and employment: A case study. Kurukshetra. 12, 18 - 23.

Gour, A. K. (2002). Factors influencing adoption of some improved animal husbandry practices of dairying in Anand and Vadodara districts of Gujarat State. Thesis, Ph.D. Gujarat Agricultural University, Sardarkrushinagar. 147p.

Gupta, L., Tank, U. N. and Dobaria, K. D. (2003). Knowledge and adoption of improved dairying practices. Agricultural Extension Review. 15(1), 30 - 31.

Gwary, M.M., Kwaghe, P.V., Jafarfuro, M.R and Dennis, A. (2011). Analysis of entrepreneurial agricultural activities of agripreneurs. Journal of Development and Agricultural Economics. 3(3),91 $-97$. 
Jhamtani, A., Sharma, J.P., Singh, R., Singh, A. and Chhibber, V. (2003). Entrepreneurial orientation of educated unemployed rural youth. Indian Journal of Extension Education. 39(3\&4), $123-132$.

Khinmaroo. (2005). Knowledge and adoption of improved dairy management practices by women dairy farmers in Dharwad district. Thesis, M. Sc. University of Agricultural Sciences, Dharwad. 368p.

Krueger, F.N., and Brazeal, V. (1994). Entrepreneurship: Theory and Practice. In:Entrepreneurial potential and potential entrepreneurs. Blackwell Publishing Ltd. 98-104p.

Kumar, N. and Narayanaswamy, B. K. (2000). Entrepreneurial behaviour and socioeconomic characteristics of farmers who adopted sustainable agriculture in India. Karnataka Journal of Agricultural Sciences. 13(1), 83 - 90.

Manjunatha, M. (2002). Impact of irrigation on annual income and employment generation in Hemavathi Project Area: A comparative analysis. Thesis, M.Sc. University of Agricultural Sciences, Bangalore. 152p.

Mahendran, S. (2004). Entrepreneurship development in agriculture. Yojana, 47(12), 19 - 20.

Meera, B. (1995). Different adoption of plant protection technology by farmers of Kerala-A critical analysis. Thesis, Ph.D. Kerala Agricultural University, Thrissur.103p.

Monica, B. and Talukdar, T.K. (1997). Variables influencing entrepreneurship of women entrepreneurs. Indian Journal of Extension Education. 33(1\&2), 25 - 34.

Naidu, V.G. (2004). Employment and income generation from TRYSEM in Anantapur district of Andhra Pradesh. Monthly Commentary. 6, 22 - 26.

Narmatha, N., Krishnaraj, R. and Mohmed Safiullah, A. (2002). Entrepreneurial behaviour of livestock farm women. Journal of Extension Education. 13(4), 343 - 438.

Nizamudeen, A. (1996). A multi-dimensional analysis of Kuttimulla (Chili) cultivation in Alapuzha district. Thesis, M.Sc. Kerala Agricultural University, Thrissur.112p.

Patel, B. S. (2005). A study of peasantry modernization in Integrated Tribal Development Project area of Dahod district of Gujarat state. Thesis, Ph. D. Anand Agricultural University, Anand. 268p.

Poswal, C.S., Mathur, G.P and Tyagi, B.D. (2006). Adoptability of sugarcane production technology. Cooperative sugar. 37(11), 31 - 34.

Rogers, E.M. (2003). Diffusion of innovations (5th ed.). New York: Free Press.

Ranuji. (2006). A study on entrepreneurial behaviour of dairy farmers. Thesis, Ph.D. University of Agricultural Sciences, Dharwad. 156p.

Reynolds,P.D. (1992). Sociology and entrepreneurship-Concepts and contributions. In: Entrepreneurship Theory and Practice. 16(2), 47 - 70. 
Sajjan, S.P., Manjunatha, M and Halakatti, S.B. (2012). A study on entrepreneurial behaviour of rural youth towards agriculture. Research Journal of Agricultural Sciences. 9(2), $131-136$.

Saravanakumar, R.(1996). A study of management of mango gardens by farmers in Krishinigiri taluk of Dharmapuri district, Tamil Nadu. Thesis, M. Sc. University of Agricultural Sciences, Dharwad. 108p.

Sawant, P.A. (1999). An experimental study on the effectiveness of different modes of presentation of information on mushroom cultivation through television. Thesis, Ph.D. University of Agricultural Sciences, Dharwad. 259p.

Shailaja, S. (1990). Role of women in mixed farming. Thesis, Ph.D. University of Agricultural Sciences, Bangalore. 284p.

Shapero. A. (1982). Social dimensions of entrepreneurship. In: Kent, C., Sexton, D., and Vesper, K. (Eds.). The encyclopedia of entrepreneurship. 72-90 pp. Englewood Cliffs, NY: Prentice Hall.

Sharma and Sohal. (1987). Adoption of cultivation and storage practices of potato. Maharashtra Journal of Extension Education. 12, 293 - 298.

Shashekala , S.G., Govinda., G.V. and Ravikumar, P. 2004. Adoption of soil and water conservation practices by groundnut farmers. Maharashtra Journal of Extension Education. 20, $117-119$.

Singh, S and Chahal, S.S. (2009). A study on the extent of various recommended technologies in wheat production in Punjab. Agricultural Economics Research Review. 22(9), 349 - 354.

Solanki, K.D., Soni, M.C. and Thakkar, K.A. (2003). Entrepreneurial behaviour of potato growers of North Gujarat. Agricultural Extension Review. 15(5), 22 - 24.

Subramanyam, I. (2002). A study on the impact of agricultural market yard committee level training programmes in Nellore district of Andhra Pradesh. Thesis, M.Sc. Acharya N.G. Ranga Agricultural University, Hyderabad.

Subramanyeswari, B. and Veeraraghavareddy, K. (2003). Entrepreneurial behaviour of rural dairy women. Madras Agricultural Journal. 30(1-3), 173 - 175.

Suresh. (2004). Entrepreneurial behaviour of milk producers in Chittoor district of Andhra Pradesh-A critical study. Thesis, M.V.Sc. Acharya N. G. Ranga Agricultural University, Hyderabad. 261p.

Venkatakumaran,R., Nanjaiyan, K., Chandrakandan, K. and Venkatapirabhu, J. (2002). Knowledge and extent of adoption of recommended coconut cultivation practices. Journal of Extension Education. 9(2), 2097 - 2100.

Vijayakumar. (2001). Knowledge and adoption of improved cultivation practices among rose growers. Indian Journal of Extension Education. 24(1), 112 - 114. 